Article

\title{
An Analysis of the Changes in the Structure of Allotment Gardens in Poland and of the Process of Regulating Legal Status
}

\author{
Anna Trembecka and Anita Kwartnik-Pruc *D \\ Faculty of Mining Surveying and Environmental Engineering, AGH University of Science and Technology, \\ 30-059 Cracow, Poland; trembec@agh.edu.pl \\ * Correspondence: akwart@agh.edu.pl; Tel.: +48-503-151-513
}

Received: 27 September 2018; Accepted: 19 October 2018; Published: 23 October 2018

check for updates

\begin{abstract}
The space occupied by allotment gardens constitutes a special element of green infrastructure and it is important for the implementation of the idea of sustainable urban development. The areas occupied for this specific purpose are decreasing throughout Europe, in those countries where allotment gardens have a long tradition and their existence is regulated by law. The aim of this research is to analyze the data on the number and area of allotment gardens, their distribution across Poland and within the exemplary city, as well as to analyze the process of regulating the legal status of the land occupied by allotment gardens. The research defined the number and area of family allotment gardens in Poland, the range of the claims against family allotment gardens and types of entities filing these claims across the country. The performed research study found that the land occupied by family allotment gardens requires protection and regulation of its legal status, which is difficult to carry out due to various entities submitting claims to these areas resulting from their attractive location in cities. The publication proposes system solutions that guarantee protection of allotment gardens, maintenance of the status quo and preservation of their current boundaries.
\end{abstract}

Keywords: allotment gardens; sustainable development; regulation of legal status; dissolution of allotment garden

\section{Introduction}

Allotment gardening significantly contributes to society's social, recreational and leisure needs. Therefore, the existence of family allotment gardens as permanent elements of infrastructure should be taken seriously into account when important decisions regarding land-use and community development are made.

On 25 September 2015, the UN General Assembly adopted the final document from the United Nations summit "Transforming our world: the 2030 Agenda for Sustainable Development" [1]. It contains 17 Sustainable Development Goals and 169 related tasks that are interdependent and indivisible, and ensure an equilibrium between the three (economic, social and environmental) aspects of sustainability. By 2030, the goals and tasks will have stimulated activities in areas of key importance for humanity and our planet.

The subject matter of this research paper concerning family allotment gardens is related to Goal No. 11 "Make cities and human settlements inclusive, safe, resilient and sustainable". In particular, the presented issues are related to specific targets, defined as follows:

- $\quad 11.3$ "By 2030, enhance inclusive and sustainable urbanization and capacity for participatory, integrated and sustainable human settlement planning and management in all countries". 
- $\quad 11.7$ “By 2030, provide universal access to safe, inclusive and accessible, green and public spaces, in particular for women and children, older persons and persons with disabilities".

The aim of this publication is to analyze the data on the number, area and distribution of allotment gardens as well as to analyze the process of regulating the legal status of land occupied by allotment gardens in order to identify these phenomena, assess them, and develop the system solutions that guarantee protection of allotment gardens, maintenance of the status quo and preservation of their current boundaries.

The research thesis is that the land occupied by family allotment gardens requires the protection and regulation of its legal status, which is difficult to carry out due to various entities submitting claims regarding these areas due to their attractive location in cities. The Act on family allotment gardens [2] that is currently in force in Poland fails to solve numerous problems that arise in practice, especially those related to the ownership structure of land occupied by the existing allotment gardens. The family allotment garden is a public utility area that plays a positive role in urban planning and the ecosystem of cities and housing estates, as well as in creating living conditions for allotment communities. The city's natural system consists of various types of ecosystems of varying degree of naturalness (Figure 1).

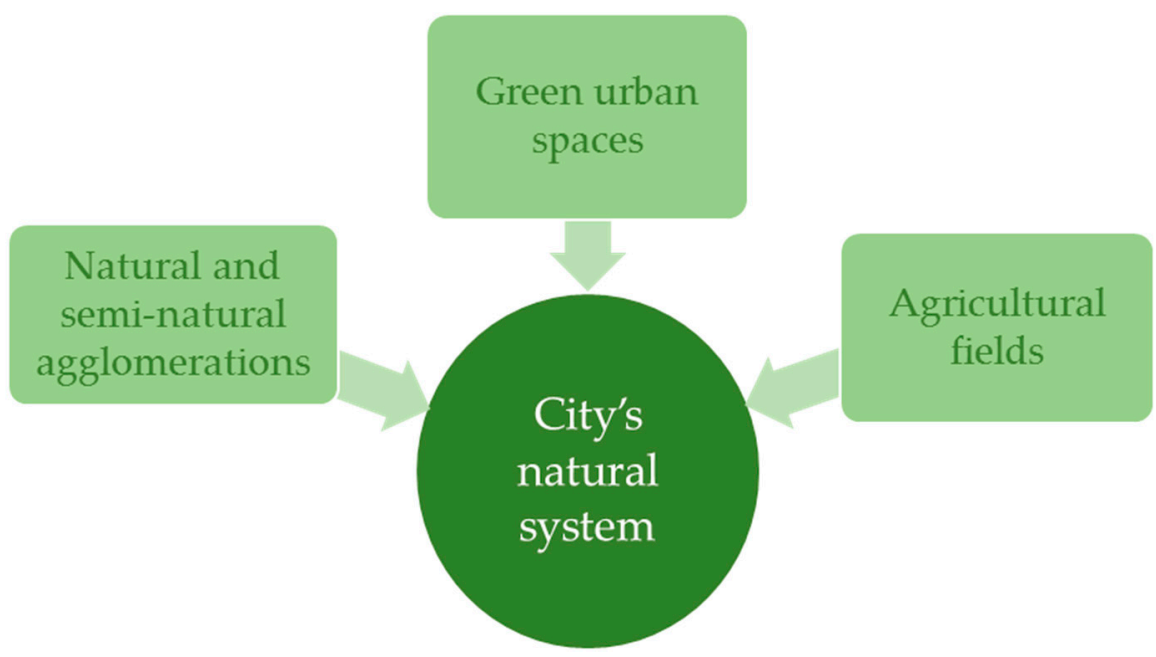

Figure 1. City's natural system [3] (Authors' own elaboration based on the reviewed literature [3]).

Green urban spaces comprise: parks and green areas, cemeteries, greenery of sports facilities, fortress greenery, nature greenery, as well as allotment gardens. The area covered by allotment gardens is important for the idea of sustainable urban development, as it is a special element of green infrastructure. According to the legal definition of sustainable development contained in Article 3 clause 50 of the Act-Environmental Protection Law [4], sustainable development should be understood as socio-economic development which integrates political, economic and social actions, while preserving the natural equilibrium and the sustainability of basic natural processes, with the aim of guaranteeing the ability of individual communities or citizens, of both the present and future generations, to satisfy their basic needs. Sustainable development is preoccupied not only with nature protection but also concern for social and civilization development related to the necessity of building appropriate infrastructure [5].

In the literature, allotment gardens are identified as a crucial green resource for the provision of urban ecosystem services [6-10]. Rapid urbanization is destroying natural ecosystems and harming the environmental quality of cities [11,12]. According to Reference [13], green infrastructure is a proven tool for strategic planning [10], which can be used to improve urban green areas [14] by creating new or revitalizing degraded ecosystems in metropolitan areas. Climate change adaptation policies for cities rely heavily on the creation of new and the preservation of the existing greenery. Therefore, 
it is possible that allotment gardens can play a role in this important field [9]. The abundance of plant species and the diversified manner of allotment garden utilization are worth emphasizing [15]. The benefits of providing urban vegetation [16], the therapeutic and nutritional value of gardens [17,18], the psychological benefits $[19,20]$, the social well-being of gardeners [21] and the benefits of local food production [22] may be some examples of this. Several authors recognize the role of vegetable gardens as a legitimate contribution to Local Agenda 21s [23-26]. Local sustainable development policies could play an important role in protecting this activity as it is very valuable for the urban environment [27].

Horticulture dates back to the 19th century when cities rapidly developed and industrialized and received an influx of thousands of people from rural areas $[23,28,29]$. The first allotment gardens were established in the United Kingdom and Germany, and they were founded as social welfare for the poorest families $[13,30]$. Based on the idea of self-help and self-sufficiency, these rental garden lots were philanthropic efforts [30]. These early urban green space infrastructures quickly turned into built-up areas due to the rapid extension of the city limits and land speculation [31]. Later on, however, the idea to provide garden lots within the city resurfaced, both as part of the pursuit of healthy living and also as an informal solution to urgent food and housing shortages. During the early stages, allotment land use was transitory, precarious and often only partly legal $[32,33]$. At the turn of the century, allotment tenants were already organized in several national federations [34]. At the beginning of the twentieth century allotment gardening gained popularity because of its capacity to provide both shelter and food during hard times. The prevailing function of the allotment gardens set up during the First World War was economic. Their main task was to yield the largest harvest possible. In the following years, the over-riding function of these gardens was to provide a healthy place for family recreation, as well as shaping social attitudes and cooperation skills [35].

The largest group of allotment holders in Poland is the Polish Garden Association-the Polish Allotment Federation, which continues the country's 120-year-old allotment movement. The Polish Allotment Federation runs 4667 family allotment gardens comprising 917,445 plots with a total area of 40,863 ha (as of 1 January 2017). The first normative act regulating the issue of allotment gardens in Poland after World War II was published in 1946. It provided for the establishment of a garden for each housing estate where at least $20 \%$ of the population lived in collective houses, deprived of gardens. Under this Act, it was also obligatory for workplaces employing more than 200 people to create such allotments. Then, four subsequent acts, including the one currently in force, were issued. Therefore, it is not possible to agree with the opinion presented by Weirich [36] that allotment gardens are only legally protected in Austria, Germany, the UK, and Slovakia. According to Reference [36], allotment federations and associations in these countries have successfully fought for legal rent control and the stable and secure use of municipally owned land. In Poland, legal regulations favor allotment tenants, while the unregulated legal status of land under the existing gardens poses a problem presented in this paper. Polish allotment gardeners collectively represent the largest land managers in Poland [37]. The currently binding Act of 13 December 2013 on family allotment gardens [2] transformed the Polish Allotment Federation into an association, and allowed for the separation of individual allotment associations into individual gardens if demanded so by allotment tenants. In Poland, allotment gardens are currently being established on land owned by the State Treasury, local government units and garden associations. The land owned by the State Treasury or local government units may either be sold by way of a contract or put into free or payable use for an indefinite period or perpetual usufruct to allotment associations for the purpose of establishing and running family allotment gardens [38]. The process of regulating the legal status of land occupied by existing gardens is subject to a separate procedure, as presented in Section 3.2.

The dissolution of the family allotment garden is possible only in exceptional cases, i.e., when the land is needed for an important public purpose or its location is inconsistent with the local land-use plan. The entity dissolving the garden is obliged to restore it. There is also the possibility of the dissolution of the entire garden or its parts due to the restitution of expropriated property. The entity that remains the owner of the property on the day of the decision on the restitution being issued, 
is obliged to restore the garden and pay compensation. It was also allowed to dissolve the garden or its parts due to the claim of a third party, with no obligation to restore the garden in this case. The garden association and allotment tenants are only paid compensation.

Despite such detailed regulations for allotment gardens in Poland, their number is constantly decreasing (Scheme 1), which is an unfavorable phenomenon. Therefore, the decision was made to investigate the situation of allotment gardens in other European countries.

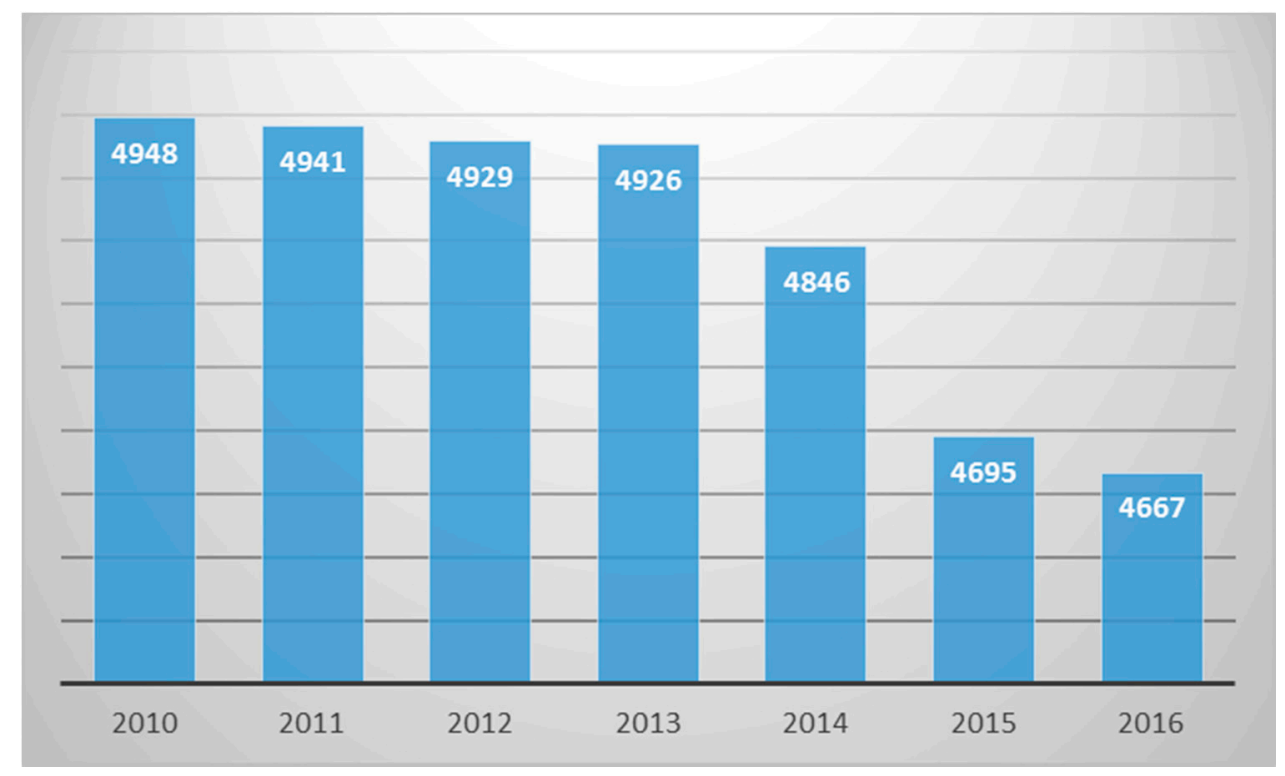

Scheme 1. Number of allotment gardens in Poland in the years 2010-2016 [39-41] (Authors' own elaboration based on the data from the Statistical Yearbooks of Agriculture of 2010-2017. Literature items [39-41]. This data is publicly available without restrictions).

Table 1 illustrates the selected criteria characterizing the legal and factual status of allotment gardens in some European countries, developed based on [29,30,33,34,42-44].

As far as changes in the area of allotment gardens in the analyzed countries are concerned, the situation is stable only in Austria and Germany where the majority of allotment gardens are located on municipally owned land, and have highly evolved organizational forms to protect allotment gardens from conversion into building sites or road infrastructure [30,34]. In other countries, there is an unfavorable tendency to decrease the areas of allotment gardens $[27,29,42-44]$. This results from the investment-attractive location of these allotments in cities on the one hand (publications), and the decreased interest in such leisure activities among the younger generation on the other [44]. This tendency is influenced both by permissible forms of ownership rights to the land occupied by allotment gardens as well as the legal status of organizations managing theses gardens. It is also of great significance that some countries do not have normative acts regulating the functioning of allotment gardens. The lack of legal protection results in greater possibilities of the land owners to dissolve allotment gardens. 
Table 1. Selected criteria characterizing legal and factual status of allotment gardens in some European countries.

\begin{tabular}{|c|c|c|c|c|c|c|c|c|c|c|c|}
\hline & \multicolumn{4}{|c|}{$\begin{array}{l}\text { Forms of Ownership Rights to Land Occupied by } \\
\text { Allotment Gardens, Permissible by Law }\end{array}$} & \multirow{2}{*}{$\begin{array}{l}\text { "Squatting" } \\
\text { Allotment } \\
\text { Gardens Set up } \\
\text { beyond Official } \\
\text { Locations }\end{array}$} & \multicolumn{2}{|c|}{$\begin{array}{c}\text { Legal Status of } \\
\text { Organisation Managing } \\
\text { Allotment Gardens with } \\
\text { Respect to Land } \\
\end{array}$} & \multicolumn{2}{|c|}{$\begin{array}{l}\text { Possibilities of Owner's } \\
\text { Disposal of Land Occupied by } \\
\text { Allotment Gardens }\end{array}$} & \multirow{2}{*}{$\begin{array}{l}\text { Possibilities of } \\
\text { Indicating } \\
\text { Allotment } \\
\text { Gardens in } \\
\text { Land-Use Plans }\end{array}$} & \multirow{2}{*}{$\begin{array}{c}\text { Existence of } \\
\text { Normative Act } \\
\text { Regulating } \\
\text { Operation of } \\
\text { Allotment Gardens }\end{array}$} \\
\hline & State & Communal & $\begin{array}{l}\text { Allotment } \\
\text { Association }\end{array}$ & Private & & Owner & $\begin{array}{l}\text { Dependent } \\
\text { Possessor }\end{array}$ & $\begin{array}{c}\text { Dissolution of } \\
\text { Allotment } \\
\text { Garden }\end{array}$ & $\begin{array}{l}\text { Land Sold to } \\
\text { Possessor }\end{array}$ & & \\
\hline Austria & & + & & & & & + & & & + & + \\
\hline Czech Republic & + & + & & + & & & + & + & + & + & draft \\
\hline Germany & & + & & & & & + & & & + & + \\
\hline Serbia & + & + & & + & + & & + & + & & + & \\
\hline Slovakia & & + & & + & & & + & + & + & + & \\
\hline Spain & + & + & & + & + & & + & + & & + & \\
\hline Poland & + & + & + & & + & + & + & +1 & & + & + \\
\hline Unite Kingdom & & + & & + & & + & + & & & + & \\
\hline
\end{tabular}

${ }^{1}$ Dissolution of allotment garden is allowed only in exceptional cases [2]. 


\section{Materials and Methods}

The aim of this research study is to present the number and area of allotment gardens in Poland, their distribution throughout the country and in the selected city. It will also analyze the process of the legal regulation of land occupied by family gardens, as well as the problems associated with this process. Moreover, the analyses aim to identify:

- the reasons behind undetermined legal status of land occupied by the existing allotment gardens,

- the methods of regulating the title to land under the current legal regulation in Poland,

- the scope of the claims regarding land occupied by allotment gardens, as well as the claimants themselves,

- the threats that may lead to the decrease in the area of allotment gardens, and the proposed solutions that guarantee that allotment gardens would remain within the city limits.

The family allotment garden, as defined in Reference [2], is a separate area or areas earmarked for allotment gardens, consisting of plots and a general access area, used for sharing by allotment tenants, and equipped with garden infrastructure. The plot is the basic spatial unit of the family allotment garden, whose area cannot exceed $500 \mathrm{~m}^{2}$, serving the needs of the tenants and their families for gardening, rest and recreation.

As public spaces, family allotment gardens are part of the green infrastructure. The legal regulations which are in force in Poland do not contain uniform provisions on public green areas per one inhabitant of a city or municipality. It can only be mentioned that the Urbanist's Guidebook [45] recommends that the total area of greenery in cities (excluding green areas on building plots) should not be less than $10 \mathrm{~m}^{2}$ of greenery per inhabitant.

The research determined:

- the number and area of family allotment gardens in Poland, with respect to individual provinces,

- the number and area of plots (gardens) located in individual allotment gardens.

The research covered the period of 2010-2016, and the data was sourced from the Statistical Yearbooks of Agriculture of 2010-2017, which are published by Poland's Main Statistical Office.

In the next step, the analysis covered the process of regulating the legal status of land under allotment gardens in the country, with regard to claims for land filed by natural and legal persons. For this purpose, the following were examined:

- the level of advancement in obtaining decisions confirming the acquisition of a title to land (right to use) in selected districts by the Polish Allotment Federation,

- range of claims against family allotment gardens in individual districts of the Polish Allotment Federation,

- types of entities filing the most (in terms of area) claims for land occupied by allotment gardens across the country,

- regulations on rights to land under allotment gardens, with regard to gardens being established and already existing ones.

The research was carried out as of 31 December 2017. The source of information was contained in the Announcement of the Polish Allotment Federation of 31 December 2017 [46].

In order to present this issue in detail, the authors analyzed the process of regulating the legal status of allotment gardens within the selected area, i.e., the city of Kraków.

Kraków, being the most recognizable city in Poland, was selected as the subject of this research study. It is also the second most important city in terms of its demographic, economic, social and cultural status. Moreover, it belongs to the group of cities which create metropolitan areas, such as Barcelona, Edinburgh or Zurich. 
The analysis of the issue within a specific area allowed us to illustrate in detail how the exemplary structure of ownership is shaped and what practical problems occur in the process of regulating the rights to land occupied by allotment gardens.

The obtained data pertained to:

- area of allotment gardens according to cadastral units,

- land ownership structure of allotment gardens,

- legal titles of the Polish Allotment Federation to land under allotment gardens,

- problems regarding the process of regulating the legal status of allotment gardens.

The relevant data of 1 January 2018 was obtained from the Treasury Department of the Municipality of Kraków, which manages public real estate and deals with establishing legal titles for lands occupied by allotment gardens.

The legal regulations on family allotment gardens in Poland were analyzed with respect to the forms of establishing the right to land, including the acquisition of the right of use by the association and its duration, conditions for the use of the gardens, fees for the use, and dissolution of allotment gardens.

The research results were collected, analyzed and presented as charts, maps, tables, and in descriptive form in Section 3.

\section{Results and Discussion}

\subsection{The Size and Distribution of Allotment Gardens across Poland and Its Provinces}

The distribution of allotment gardens in Poland is not uniform throughout the country. There are areas with a high concentration of these gardens as well as areas with a relatively small concentration. In order to analyze the areas of family allotment gardens existing in Poland in individual provinces as well as trends in their areas gradually decreasing, a cartogram was developed containing the data on the areas of allotment gardens in 2006 and 2016 (Scheme 2).

It is noticeable that a large concentration of allotment gardens occurs in highly industrialized provinces such as: Lower Silesia [pl: dolnoślaskie], Silesia [pl: ślaskie] or Greater Poland [pl: wielkopolskie]. This fact results from the historical conditions described in the Introduction. The decree on allotment gardens of 1946 [47] imposed the obligation on the municipalities to set up family gardens for each housing estate in which at least $20 \%$ of the population lived in collective houses, deprived of gardens. In addition, it was compulsory for the institutions employing more than 200 people to establish such allotments. Hence, in the provinces where the industry dominated and where the workers migrated in search for employment opportunities, the areas of allotment gardens are the largest.

In 2016, there were 4667 allotment gardens in Poland, which consisted of 917,445 plots, and their total area was 40,863 hectares (data of the Central Statistical Office of 2017). This area decreased from 43,662 ha in 2006 to 40,863 ha in 2016 , which is by almost $7 \%$ in ten years. The same phenomenon applied to the plots themselves, whose area decreased by almost $5 \%$ when compared to 2006 . However, a large area of allotment gardens in a given province did not translate into a large decrease in their area over the analyzed ten years. The largest decrease in the number of allotment gardens was noted in Mazovia [pl. mazowieckie], Lower Silesia [pl. dolnoślaskie], Pomerania [pl. pomorskie] and Lesser Poland [pl: małopolskie], where the largest Polish cities are located. In these cities, investment areas are the most valuable ones. 


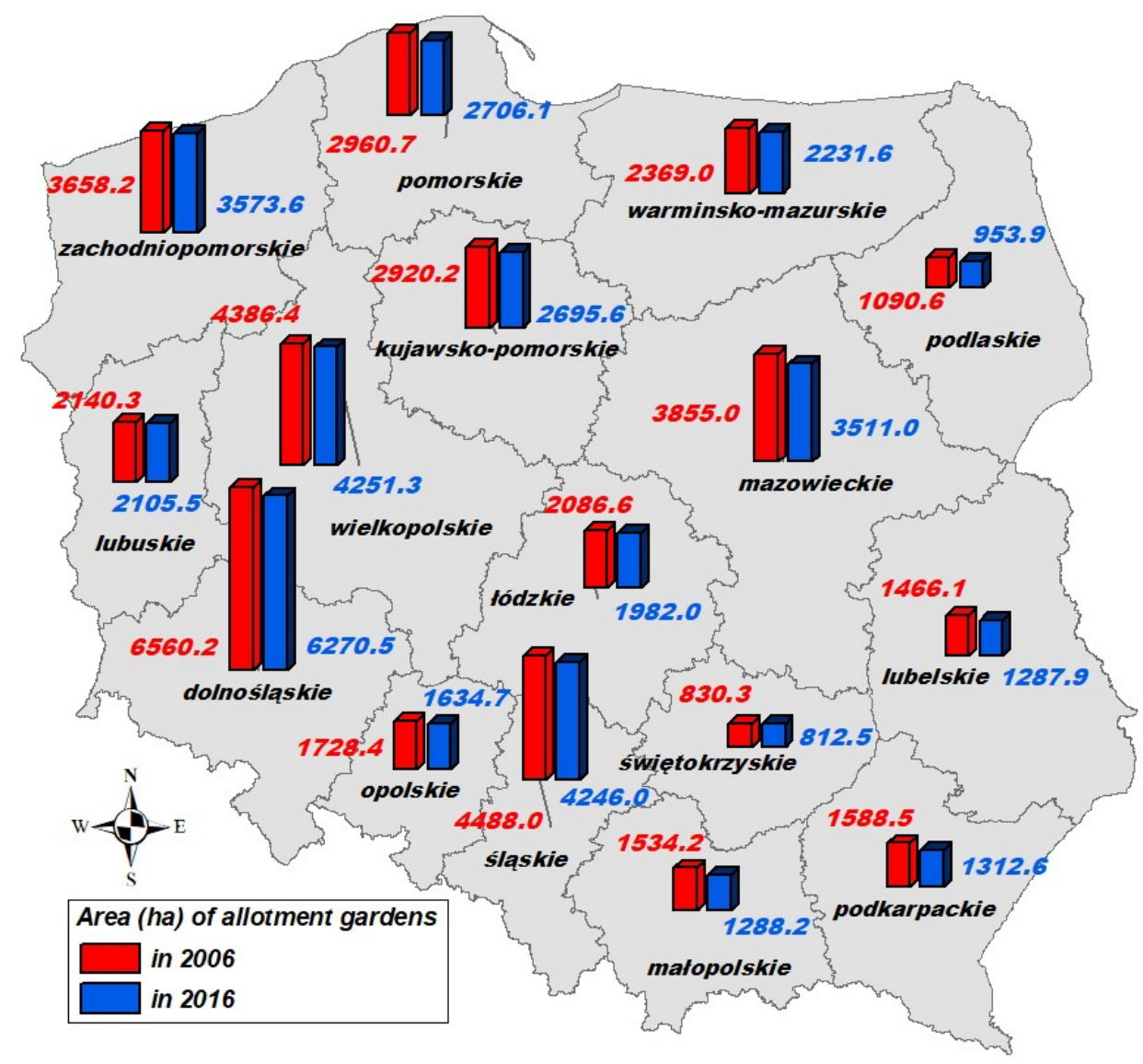

Scheme 2. Changes in areas (ha) of allotment gardens in Poland in 2006 and 2016 [39-41] (Authors' own elaboration based on the data from the Statistical Yearbooks of Agriculture of 2010-2017. Literature items [39-41]. This data is publicly available without restrictions).

Scheme 3 illustrates the detailed data regarding individual provinces. It is clearly visible that the following provinces exhibit the largest number of allotment gardens: Silesia [pl: śląskie] (663), Lower Silesia [pl: dolnośląskie] (528) and Greater Poland [pl: wielkopolskie] (513). However, when it comes to their area, the largest is in Lower Silesia (6270.5 ha), followed by Greater Poland (4251.3 ha) and Silesia (4246 ha). It proves that the large number of allotment gardens does not necessarily translate into their large area. In Silesia [pl: ślaskie], there is the largest industrialization and the largest population density in Poland. Thus, the area of individual gardens here is smaller than in other provinces. The smallest number of allotment gardens was recorded in the following provinces: Świetokrzyskie (79) with a total area of 812.5 ha and Podlaskie (99) with a total area of 953.9 ha, where agriculture and single-family housing prevails. 


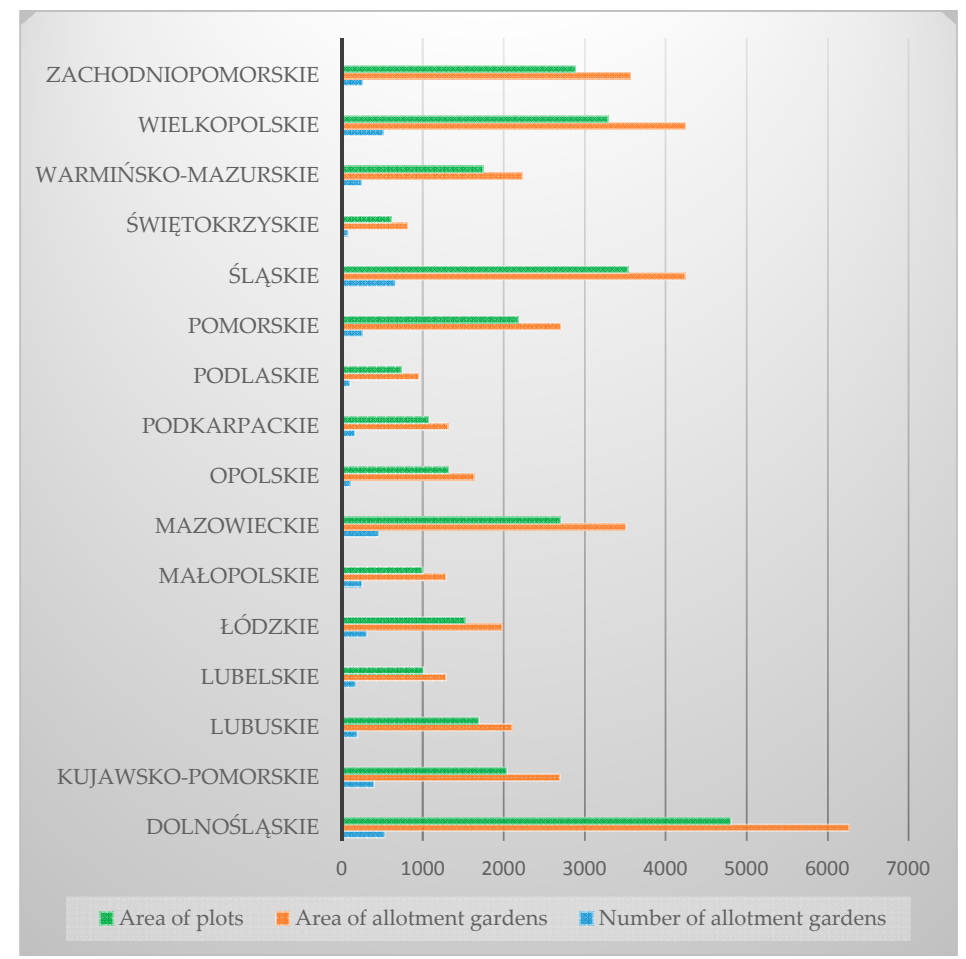

Scheme 3. Data on allotment gardens in individual provinces in 2016 [41] (Authors' own elaboration based on the data from the Statistical Yearbooks of Agriculture of 2017. Literature item [41]. This data is publicly available without restrictions).

\subsection{The Process of Regulating the Legal Status of Land Occupied by Allotment Gardens}

Since the Act on family allotment gardens entered into force, i.e., since 18 January 2014, the Polish Allotment Federation has been taking steps to obtain decisions confirming the right to land with an undetermined legal status, occupied by allotment gardens. These actions may be taken based on legal solutions contained in the Act of 13 December 2013 on family allotment gardens [2], and are applicable to those allotment gardens that are located on properties owned by the State Treasury or local government units, and meeting even one of the premises set forth in Article 76 of the Act [2].

As of 19 January 2014, the legislator provided for the possibility of acquisition of the right of use of such gardens by allotment associations provided that at least one of the following conditions is met:

1. the family allotment garden operates on the property in accordance with the local land use plan;

2. the family allotment garden has been operating on the property for at least 30 years, and the acquisition of the ownership right to the property by the State Treasury was effected as a result of the establishment of the family allotment garden on this property, or it had already functioned on the property at the time when the State Treasury acquired the ownership rights to it;

3. the family allotment garden has been operating on the property for at least 30 years, and the acquisition of the ownership right to the property by the local government unit resulted from the allotment garden functioning on this property;

4. the property is occupied by the allotment garden which had a fixed location on the day of entry into force of the Act of 6 May 1981 on employees' allotment gardens, or which, pursuant to Article 11 Section 3 or Article 33 of this Act, has become a permanent allotment garden.

The right of use is indefinite. The terms of use consist in the association being allowed to use the real property to run allotment gardens on condition of being obliged to pay the current costs of maintenance and taxes, taking care of the property, implementing investment projects. In the event of non-compliance with these terms of use, it is possible to terminate the right of use under the terms of the Civil Code [48]. 
The Act on family allotment gardens does not specify whether or not allotment associations acquire the right of use for a fee or free of charge. According to some views, the purpose of the Act was to establish free and unlimited use of the gardens. Regardless of the intentions that probably guided the citizens' bill on family gardens, so that the land use would be free, they were not reflected in the final form of the Act.

Some cities have adopted annual rates for the use of land by allotment associations, for example, in Kraków, this rate is $0.02 \%$ of the value of the property. The values of the land are determined by real estate appraisers in valuation reports. However, the decisions determining the fees for the use are revoked by appeal bodies with the recommendation of free use. Allotment gardens are managed by the Polish Allotment Federation, who establishes rights to the plots for the benefit of natural persons under a lease agreement. Under the provisions of this lease agreement, the allotment association undertakes to let the plot for use and for gain of the profits à prendre for an indefinite period of time, and the tenant is obliged to use the plot according to its intended purpose, obey the regulations and pay allotment fees.

The garden association may let a plot of land into free use to the institutions that perform social, educational, cultural, rehabilitation, charitable or social care activities. Land maintenance and investment outlays are financed from the association's and tenants' own funds.

Although the acquisition of the right of use is recognized by virtue of law, the Act [2] provides for an official procedure for determining the acquisition of this right in the form of an administrative decision [49] issued by the district governor when the allotment garden is located on the property owned by the Treasury, or by the executive body of the local government unit when the allotment garden is located on the property owned by the local government unit.

Until now, as of 1 January 2018, the Polish Allotment Federation has obtained decisions confirming the right of use to 1000 allotment gardens with an area of nearly 5000 ha, which accounts for $48 \%$ of the total area covered by the regulation. In 2017, the authorities issued decisions confirming the right of use to 200 family allotment gardens, covering an area of over 1100 ha.

Currently, the submitted applications cover an area of over 5350 ha. They have a pending status and are to be considered by public administration bodies. The level of advancement in obtaining decisions confirming the right of use for the Polish Allotment Federation in selected districts is presented in Scheme 4.

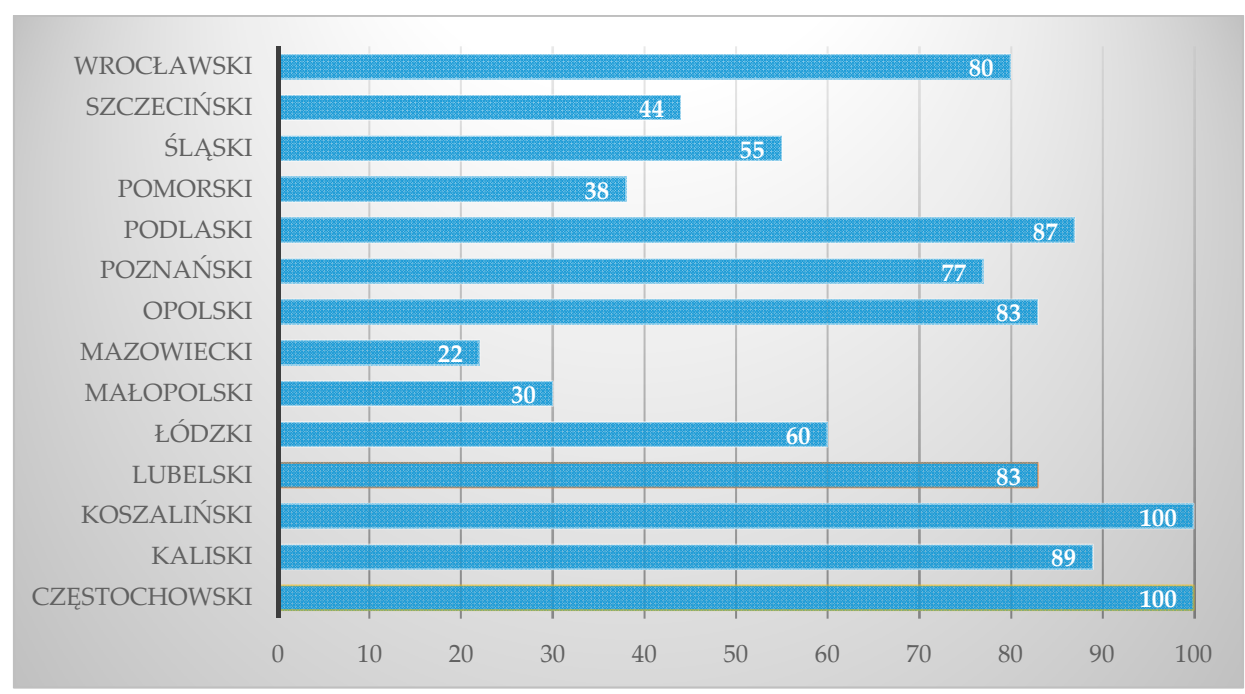

Scheme 4. The level of advancement (\%) in obtaining decisions confirming the acquisition of the right of use by the Polish Allotment Federation in selected districts [50] (Authors' own elaboration based on the data from the Announcement of the Polish Allotment Federation on the Regulation of the Legal Status of Land in Family Allotment Gardens. Literature item [50]. This data is publicly available without restrictions). 


\subsection{Analysis of the Status of Claims for Land Occupied by Allotment Gardens}

In the past, allotment gardens were often established on private land or land with undetermined legal status, which is why there are numerous claims being filed today by various entities regarding land occupied by the existing allotments.

The research demonstrated that as of 1 January 2018, 329 allotment gardens with a total area of 845.3502 ha, consisting of 19,159 plots, were covered by claims (Table 2). The aforementioned claims are divided into claims implemented by way of court or administrative proceedings ("active" claims) and those that are not implemented by way of court or administrative proceedings ("dormant" claims).

"Active" claims cover 206 allotment gardens with an area of 607.6690 ha and 14,479 plots. "Dormant" claims cover 123 allotment gardens with an area of 237.6812 ha and 4680 plots.

Table 2. Claims against allotment gardens as of 31 December 2017 in individual districts of the Polish Allotment Federation [46] (Authors' own elaboration based on the data from the Announcement of the National Council of the Polish Allotment Federation on Claims to Land Occupied by Allotment Gardens. Literature item [46]. This data is publicly available without restrictions).

\begin{tabular}{cccc}
\hline $\begin{array}{c}\text { District of Polish } \\
\text { Allotment Federation }\end{array}$ & Number of Plots & $\begin{array}{c}\text { Area of Allotment } \\
\text { Gardens [ha] }\end{array}$ & $\begin{array}{c}\text { Number of Allotment } \\
\text { Gardens }\end{array}$ \\
\hline mazowiecki & 7727 & $3,608,361$ & 92 \\
małopolski & 2253 & 297,188 & 49 \\
śląski & 1844 & 696,466 & 41 \\
pomorski & 1219 & 476,824 & 12 \\
podlaski & 935 & 466,744 & 8 \\
podkarpacki & 717 & 270,912 & 10 \\
toruńsko-włocławski & 602 & 227,166 & 18 \\
poznański & 567 & 365,343 & 19 \\
łódzki & 512 & 20,956 & 13 \\
wrocławski & 505 & 239,365 & 5 \\
lubliński & 361 & 123,427 & 73 \\
szczeciński & 350 & 1816 & 9 \\
świętokrzyski & 317 & 90,718 & 4 \\
warmińsko-mazurski & 283 & 9872 & 3 \\
bydgoski & 254 & 103,896 & 7 \\
opolski & 248 & 8934 & 4 \\
kaliski & 189 & 85,274 & 6 \\
sudecki & 149 & 132,561 & 4 \\
częstochowski & 60 & 66,626 & 4 \\
pilski & 60 & 21,668 & 1 \\
gorzowski & 7 & 2539 & 329 \\
\hline Total & $\mathbf{1 9 , 1 5 9}$ & $\mathbf{8 , 4 5 3 , 5 0 2}$ & \\
\hline
\end{tabular}

The above Table demonstrates that claims of various entities covered as many as 329 allotment gardens in Poland, with a total area of over 845 ha. The claims covering the largest area were filed in the district of Mazovia [pl: mazowiecki] (about 361 ha), which includes Poland's capital city (Warsaw), Silesia [pl: ślaski] (about 70 ha), where heavy industry is located and Pomerania [pl. pomorski] (about $48 \mathrm{ha}$ ). These districts cover the provinces listed in Section 3.1 as the ones with the greatest decrease in the areas of allotment gardens.

The next chart [Scheme 5] illustrates entities filing claims for land occupied by allotment gardens (in terms of area). It is noteworthy that the largest group are natural persons whose claims cover $48 \%$ of the land. The second are local government units (38\%), followed by legal entities $(9 \%)$. 


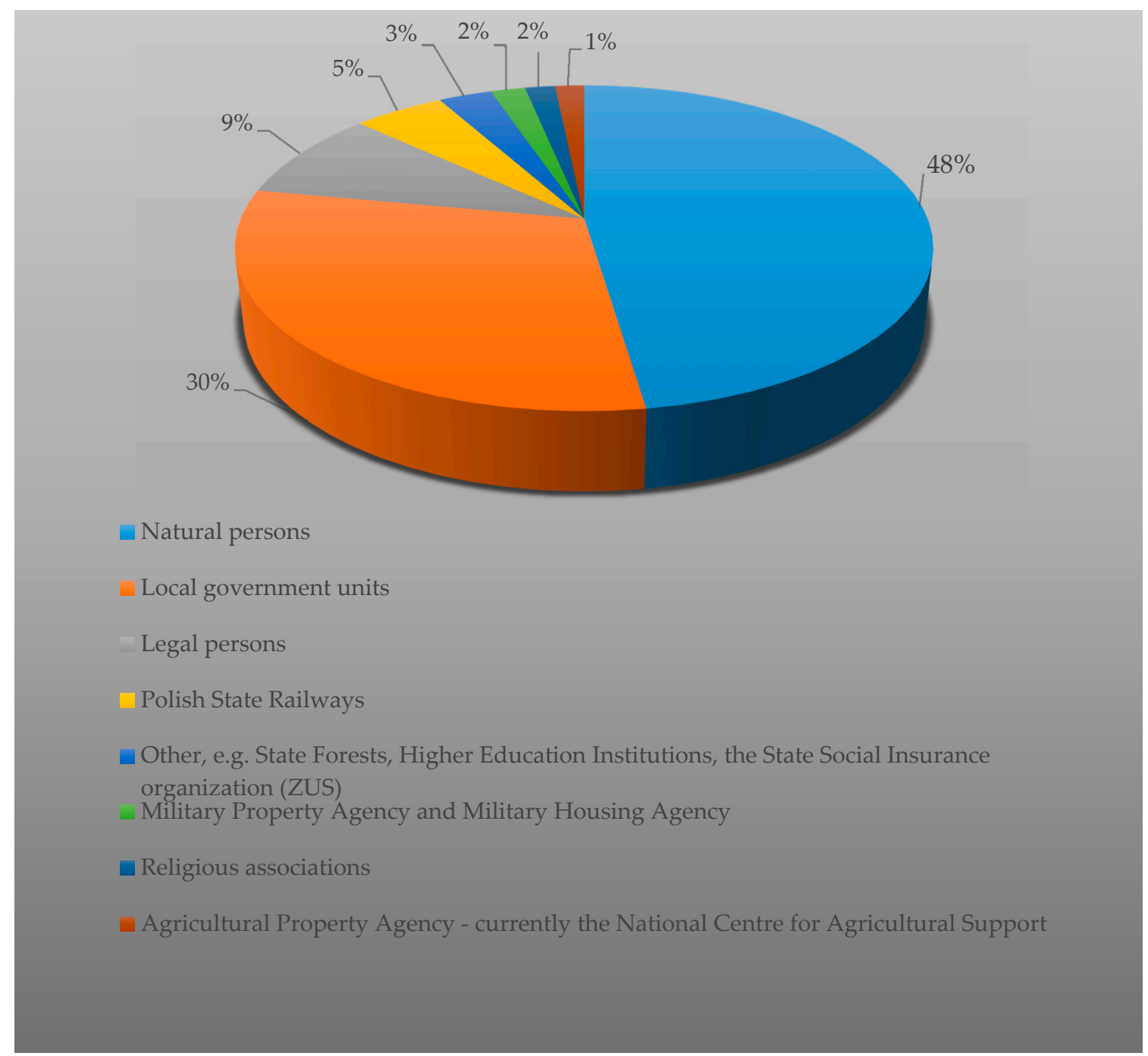

Scheme 5. Entities filing claims for land occupied by allotment gardens (in terms of area) [46] (Authors' own elaboration based on the data from the Announcement of the National Council of the Polish Allotment Federation on Claims to Land Occupied by Allotment Gardens. Literature item [46]. This data is publicly available without restrictions).

\subsection{Allotment Gardens in Kraków and the City's Natural System}

In addition to natural conditions, historical conditions have played an important role in the way green areas are managed in Kraków. As a result, historic garden projects have been created, both in the city center and on the outskirts of the city, as well as the fortress greenery system providing the city with approximately 282 hectares of greenery with great cultural, landscape and natural values.

All elements of the open area system shape the living conditions and the city landscape. However, the possibilities of them being used as urban green areas vary, e.g., they are limited in the case of allotment gardens. Many allotment gardens, both official and "squatting", deserve attention for nature-related reasons. Numerous species of herbaceous and woody plants have been introduced to these areas.

The document "Directions of the development and management of green areas in Kraków for the years 2017-2030" is currently being prepared at the Department of Environmental Management of the Municipality of Kraków, which also implements the objectives of the National Urban Policy in relation to projects aimed at improving urban greenery systems. The document indicates that due to vast areas occupied for development in the city and the lack of recreational green areas, allotment 
gardens perform their social function not only for the tenants, but also for the entire community of the inhabitants of Kraków.

In the "Kraków Development Strategy. I want to live here. Kraków 2030" adopted by the resolution of the Kraków City Council [51] emphasis was placed on the development of greenery systems. One of the strategic goals mentioned was "Kraków-a friendly city to live in" which points to a "sustainable environment" as one of its operational objectives.

On 14 September 2016, the Kraków City Council adopted the Allotment Garden Support Program for the family gardens in the Municipality of Kraków. The purpose of the Allotment Garden Support Program is to promote gardening and popularize recreation, rest and leisure in green areas. The program also encourages Garden Associations to create areas in Family Allotment Gardens which would be accessible for all inhabitants. It will also allow the effective use of financial resources granted by the Municipality, thanks to which the renovation of gardens will be carried out. It will significantly improve the use of green areas by both the allotment tenants and the inhabitants of Kraków.

Thanks to the program, allotment tenants will be able to receive a designated subsidy for the construction, modernization and development of infrastructure (e.g., building a day-care center or a playground) or enter into an agreement with the Municipality on retrofitting the allotment garden with public infrastructure. The condition for obtaining both forms of support is making the garden accessible for the inhabitants of Kraków.

It is planned to grant subsidies based on the analysis of the surveys concerning individual allotment gardens with a description of the condition of the structures requiring renovation, their intended purpose and the needs of the local community.

As reported by the Polish Allotment Federation, the Małopolska District-the Municipality of Kraków - was the first in Poland to offer help to Family Allotment Gardens on such a large scale.

The team working on the program was focused primarily on identifying optimal and law-abiding methods as well as actions aimed at ensuring the further existence and development of allotment gardens located in Kraków as permanent elements of the city's infrastructure, as well as encouraging Allotment Garden Associations to open the gates of Kraków's allotment gardens in exchange for the help offered by the Municipality.

\subsection{Ownership Structure of Land Occupied by Allotment Gardens in the City of Kraków}

As part of the research, the ownership structure of land occupied by allotment gardens was determined for the selected city, i.e., Kraków. These areas are a valuable aesthetic and ecological element, affecting the health of inhabitants as well as the development of the social and cultural life of the local community. Allotment gardens are an integral part of urban infrastructure, serving the tenants and inhabitants of nearby areas (Figure 2).

The map illustrates the location of allotment gardens in Krakow. It also presents the main communication routes and buildings, which allows us to assess the distribution of allotment gardens in relation to the city's tissue. Due to the extensive area of the city, the inclusion of other information would make the map illegible. The analysis demonstrates that the gardens are located in the eastern, western and southern parts of Kraków, very close to the center of the city, with few of them near the city limits. In most cases, allotment gardens are located near buildings. Peripheral areas of the city are devoid of allotment gardens. Location of the gardens near the developed areas may result from their communication accessibility as well as from the fact that in recent years new gardens have not been established, and the city has been expanding rapidly. 


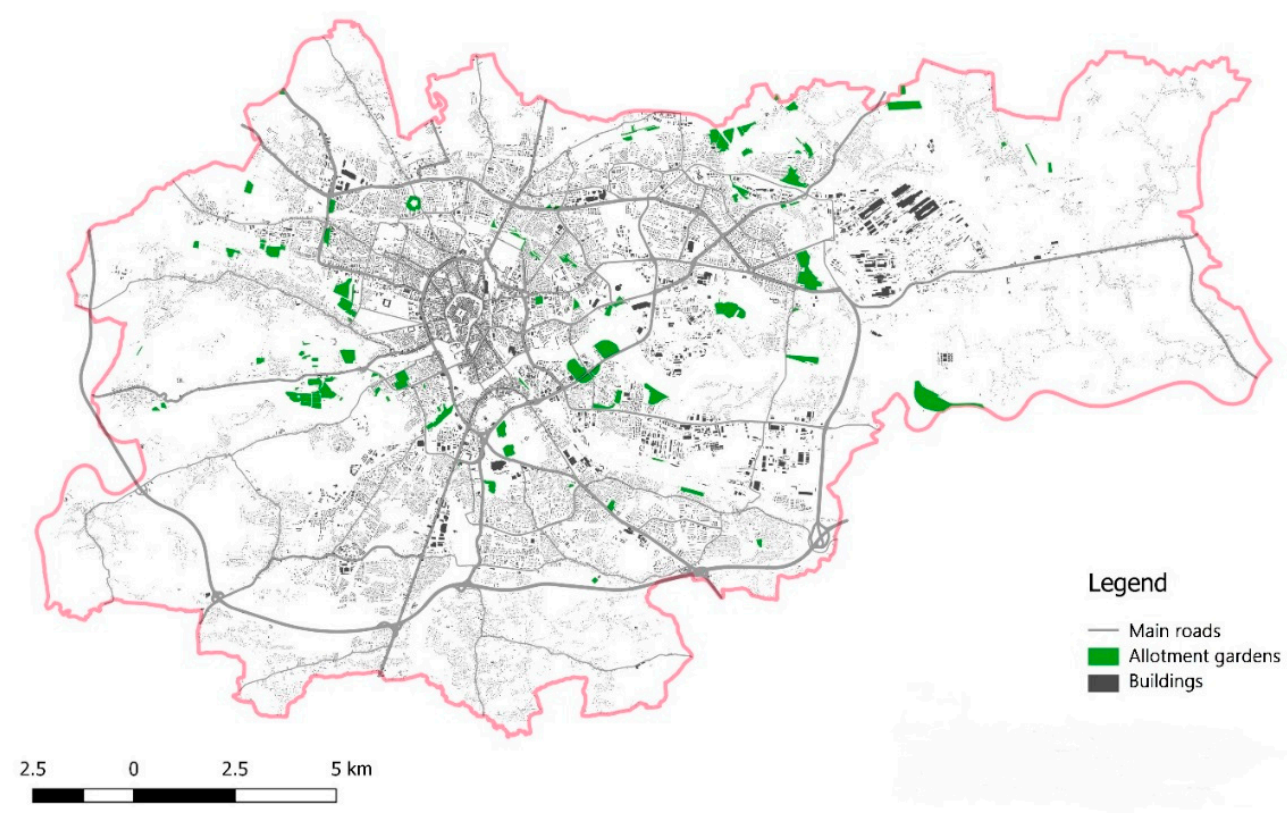

Figure 2. The distribution of allotment gardens in Kraków [52] (Authors' own elaboration based on the Literature item [52]).

There are 87 permanently developed allotment gardens located on land of various ownership status, including private land [53]. Their total area exceeds 470 hectares, which accounts for about $1.5 \%$ of the city's area (as of 31 December 2017). These are often beautifully developed plots in attractive locations (Figure 3).
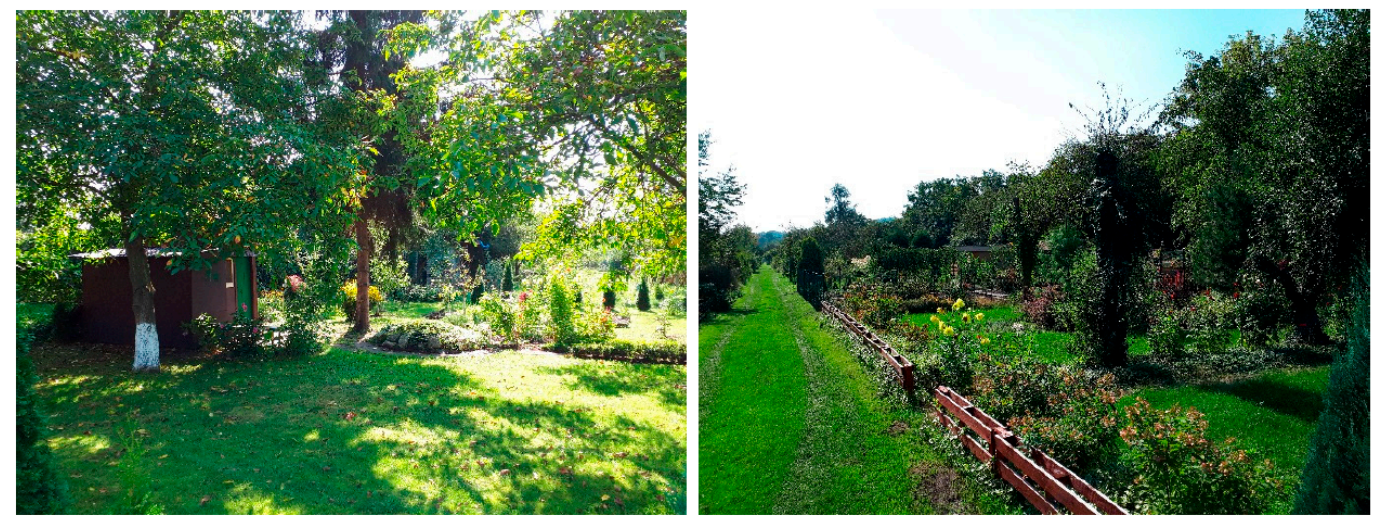

Figure 3. Fragment of plots beside Buszka street (10 September 2018).

Analysis of the legal status of allotment gardens in Kraków (Scheme 6) demonstrates that most of them are located on properties owned by the Municipality of Kraków (380.9 ha) or the State Treasury (65.1 ha). However, some allotment gardens are located on land owned by natural persons and legal persons (11.6 ha) or jointly owned by these entities (12.7 ha). None of them is located on land owned by the Polish Allotment Federation. 


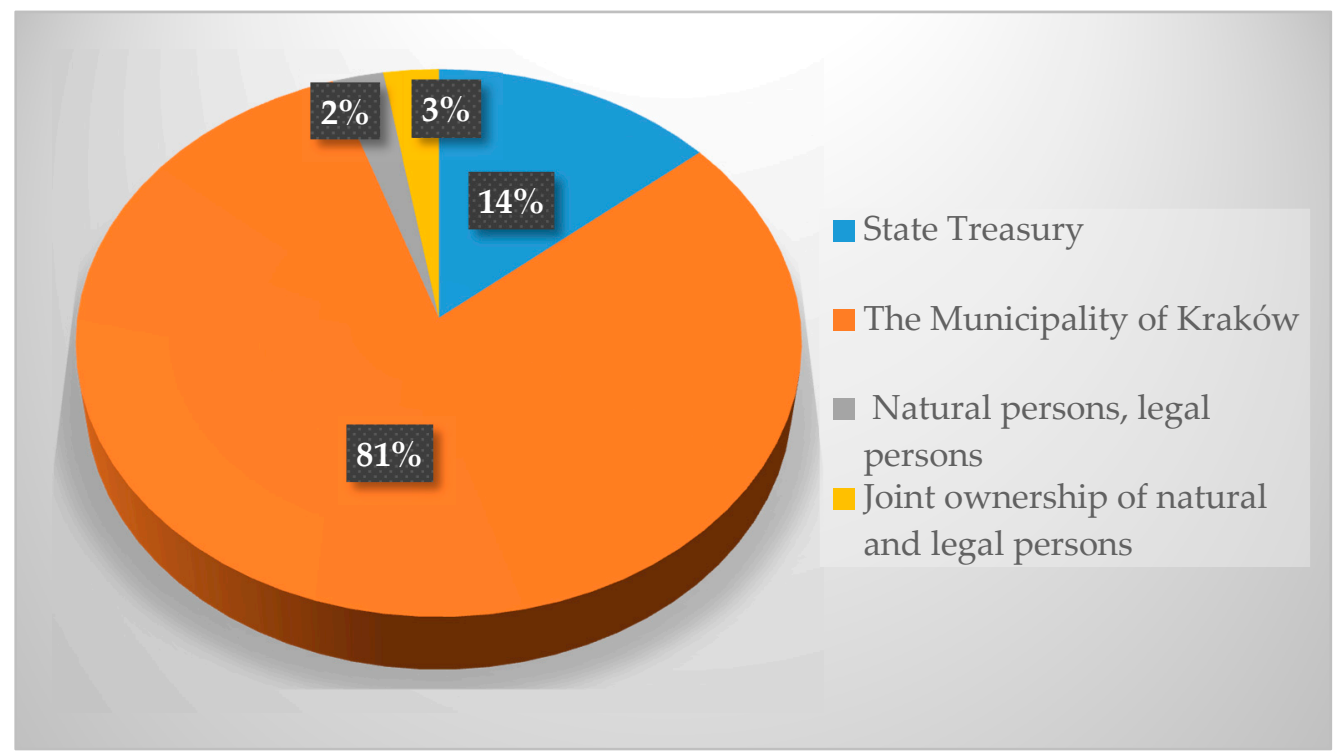

Scheme 6. The ownership structure of land occupied by allotment gardens in Kraków [53].

In Kraków, the vast majority of allotment gardens are run by the allotment association-the Polish Allotment Federation-Małopolska District in Kraków. Studies have revealed that the association does not hold a legal title to the vast majority of lands occupied by family allotment gardens. It only holds a full title to the land in the form of the right of use or the right of perpetual usufruct in the case of eight allotment gardens. This title was obtained based on previously applicable laws on employee and family allotment gardens. It also holds a partial title in relation to four allotment gardens [53]. The area of land to which the association holds a legal title is about 50 ha, which accounts for only about $10 \%$ of the total area of allotment gardens. The association has no legal title to 75 allotment gardens, and holds a partial title to four allotment gardens. This means that the association has no title to the total area of approximately 420.3 hectares; however, it has made efforts to obtain the right to this land. This data demonstrates the scale of the problem and emphasizes the necessity to regulate the possession of allotment gardens by authorized entities.

The performed research studies have revealed that there are numerous proceedings pending before the administrative authorities and common courts that may result in depriving the Municipality of Kraków and the State Treasury of ownership of part of the land occupied by allotment gardens. These proceedings concern:

- the restitution of expropriated properties to former owners, subject to the provisions of the Real Estate Management Act [54,55],

- the annulment of expropriation decisions,

- the acquisitive prescription of land by natural and legal persons.

The restitution of expropriated property results in the dissolution of an allotment garden or part of it, and the entity that owns the property on the day the decision on restitution is issued is obliged to restore the garden and pay compensation.

\section{Conclusions}

Allotment gardening contributes to the satisfying social, recreational and leisure needs of society. The allotment space is also important in the implementation of the idea of sustainable urban development, as it constitutes a special element of green infrastructure.

The increased development of urban agglomerations, however, results in the areas of allotment gardens, often situated in attractive locations of the city, gradually decreasing. This is exemplified by the city of Kraków, where allotments are very close to its central part, near the buildings, with only a 
few of them near the city limits. Land occupied by family allotment gardens, located in city centers, is of great interest to investors implementing residential and commercial development. This is a problem not only in Poland but in other countries as well. Only in two of the countries analyzed in this research paper-Austria and Germany-the situation is stable. This is due to the legal status of the land which is municipally owned, as well as highly evolved organizational forms of the allotment gardens. All this has been worked out over the decades and unambiguously stipulated in the existing legal acts.

In Poland, allotment gardening is still a huge social movement, despite the fact that their areas are constantly decreasing. After all, in 2017, there were 917.445 plots of land cultivated by gardeners. Despite the continuous legal regulation over the last 70 years, the system which was in Poland after the Second World War, together with the imprecise provisions, resulted in the existing allotment gardens not always being located on public lands, and often not having a legal title to occupy these land. However, even the location of allotment gardens on public lands does not guarantee that they will not be dissolved. This is due to the claims for restitution filed by the former owners, if the allotment gardens are located on land expropriated for other purposes. In addition, allotment associations do not hold a legal title to the majority of the plots, as exemplified by the city of Kraków. The Act on allotment gardens [2], which is currently in force in Poland, allowed allotment association to obtain a legal title to some of the lands occupied by allotment gardens, but it does not solve numerous problems that arise in practice, related e.g., to the structure of ownership of land occupied by the existing gardens. In Kraków, which is one of the most expensive cities in Poland in terms of property prices, undetermined legal status of land under allotment gardens results in slow development of these areas (Figure 4).

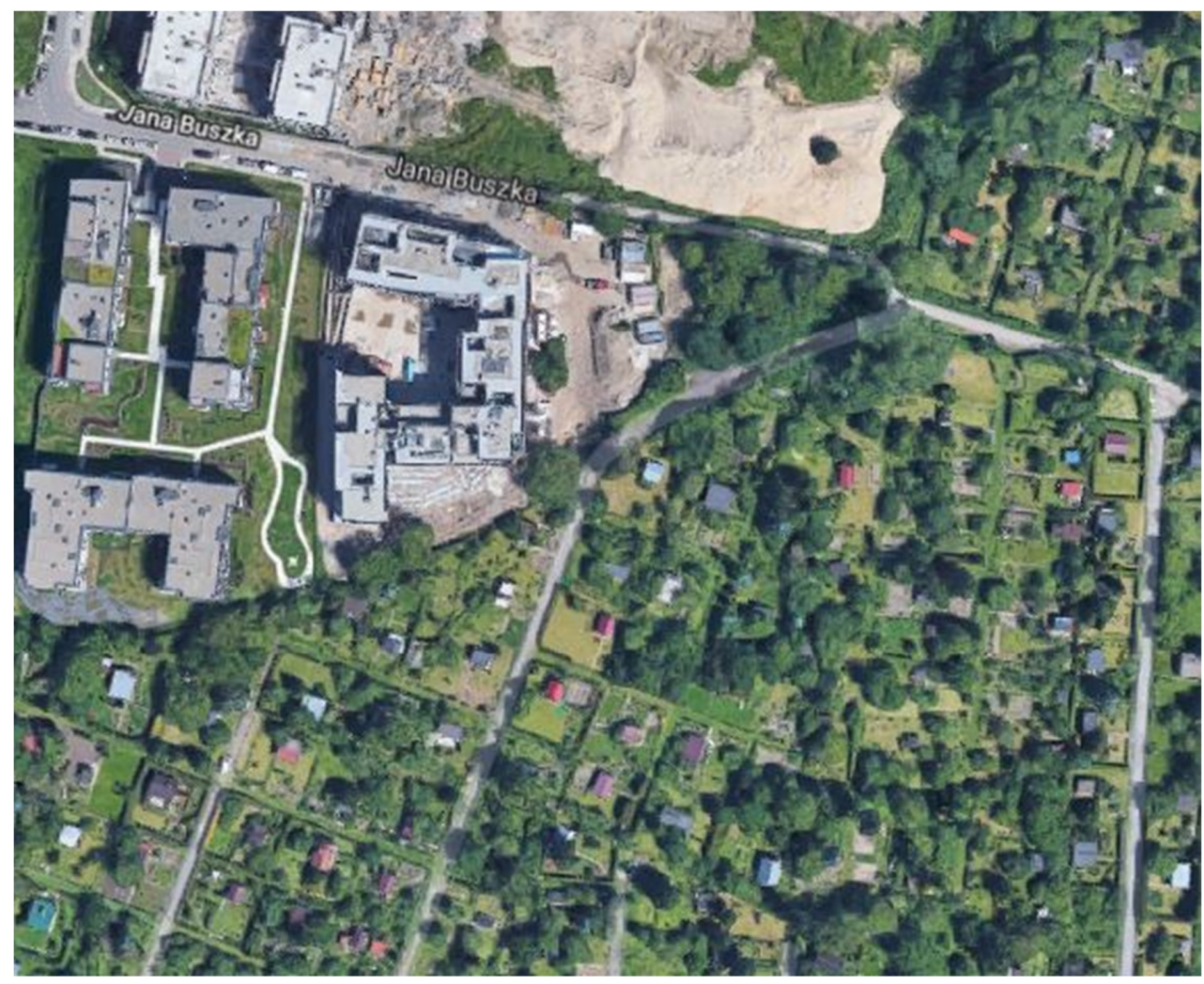

Figure 4. Residential development near the allotment garden in Buszka street [56].

Due to the fact that similar problems occur in other countries as well, the following system solutions are proposed that will guarantee (enable) the protection of allotment gardens and that they remain in the existing state and within the existing boundaries: 
- creating (modifying) legal acts at the national level, precisely regulating the principles of the location and the rules of functioning of allotment gardens,

- locating allotment gardens exclusively on public lands (they may be acquired from other entities for this purpose as well; the owner is important when the garden is being established),

- the adoption of land-use plans with the defined function of greenery for allotment gardens in order to eliminate their other use in the future,

- the introduction of an obligation that in the case of the dissolution of allotment gardens they are to be restored in a different location with a similar surface area,

- the introduction of an obligation that in the absence of interest of tenants in a given garden, it may only be replaced with another element of urban greenery,

- the satisfaction of claims for land occupied by allotment gardens in the form of pecuniary compensation or substitute real property, instead of their dissolution.

Examples of positive legal solutions, which are also worth introducing in other countries, are the Polish regulations that oblige the dissolving entity to set up a new garden and restore the facilities and buildings corresponding to the type of facilities and buildings being eliminated. A similar obligation is binding in the case of the dissolution of an allotment garden resulting from the restitution of expropriated property.

Author Contributions: Conceptualization, A.T. and A.K.-P.; Methodology, A.T.; Formal Analysis, A.T.; Investigation, A.T. and A.K.-P.; Resources, A.T. and A.K.-P.; Data Curation, A.T. and A.K.-P.; Writing-Original Draft Preparation, A.T. and A.K.-P.; Writing—Review \& Editing, A.K.-P.; Visualization, A.K.-P.

Funding: The study was carried out with financial support from the statutory research No. 11.11.150.005 from the AGH University of Science and Technology in Krakow.

Conflicts of Interest: The authors declare no conflict of interest.

\section{References}

1. Transforming Our World: The 2030 Agenda for Sustainable Development. Available online: http://www.un. $\mathrm{org} / \mathrm{ga} / \mathrm{search} /$ view_doc.asp?symbol=A/RES/70/1\&Lang=E (accessed on 25 July 2018).

2. The Act of 13 December 2013 on Allotment Gardens. Official Journal of 2014, Item 40 (as Amended). Available online: http:/ / prawo.sejm.gov.pl/isap.nsf/download.xsp/WDU20170002176/T/D20172176L.pdf (accessed on 4 March 2018).

3. Study of Conditions and Directions of Spatial Development of the Municipality of Kraków, as Amended by the Resolution of the City Council of Kraków of July 9, 2014. Available online: www.bip.krakow.pl/?mmi=48 (accessed on 4 March 2018).

4. The Act of 27 April 2001 Environmental Protection Law. Official Journal of 2018, Item 799 (as Amended). Available online: http:/ / prawo.sejm.gov.pl/isap.nsf/download.xsp/WDU20180000799/U/D20180799Lj. pdf (accessed on 4 March 2018).

5. Judgment of the Constitutional Tribunal of 6 July 2006. Official Journal of 2006, No. 106, Item 720. Available online: http:/ / prawo.sejm.gov.pl/isap.nsf/download.xsp/WDU20061060720/T/D20060720L.pdf (accessed on 4 March 2018).

6. Breuste, J.H. Allotment Gardens as Part of Urban Green Infrastructure: Actual Trends and Perspectives in Central Europe. In Urban Biodiversity and Design; Müller, N., Werner, P., Kelcey, J.G., Eds.; Wiley-Blackwell: Oxford, UK, 2010; pp. 463-475.

7. Barthel, S.; Isendahl, C. Urban gardens, agriculture, and water management: Sources of resilience for long-term food security in cities. Ecol. Econ. 2013, 86, 224-234. [CrossRef]

8. Gómez-Baggethun, E.; Barton, D.N. Classifying and valuing ecosystem services for urban planning. Ecol. Econ. 2013, 86, 235-245. [CrossRef]

9. Speak, A.F.; Mizgajski, A.; Borysiak, J. Allotment gardens and parks: Provision of ecosystem services with an emphasis on biodiversity. Urban For. Urban Green. 2015, 14, 772-781. [CrossRef]

10. Lovell, S.T. Multifunctional Urban Agriculture for Sustainable Land Use Planning in the United States. Sustainability 2010, 2, 2499-2522. [CrossRef] 
11. Alberti, M.; Marzluff, J.M. Ecological resilience in urban ecosystems: Linking urban patterns to human and ecological functions. Urban Ecosyst. 2004, 7, 241-265. [CrossRef]

12. Ahern, J. Green infrastructure for cities: The spatial dimension. In Cities of the Future: Towards Inte-Grated Sustainable Water and Landscape Management; Novotny, V., Brown, P., Eds.; IWA Publishing: London, UK, 2007; ISBN 1843391368. Available online: https:/ / people.umass.edu/jfa/pdf/Chapter17_Ahern2\%20copy.pdf (accessed on 4 March 2018).

13. Szczepańska, M.; Krzyżaniak, M.; Świerk, D.; Urbański, P. Rodzinne ogrody działkowe jako element zielonej infrastruktury na terenie aglomeracji poznańskiej. Studia Miejskie 2016, 22, 129-142. Available online: http:/ /www.studiamiejskie.uni.opole.pl/wp-content/uploads/2016/09/S_Miejskie_22_ 2016-Szczepanska.pdf (accessed on 4 March 2018).

14. Tzoulas, K.; Korpela, K.; Venn, S.; Vli-Pelkonen, V.; Kazmierczak, A.; Niemela, J. Promoting ecosystem and human health in urban areas using Green Infrastructure: A literature review. Landsc. Urban Plan. 2007, 81, 167-178. [CrossRef]

15. Klepacki, P.; Kujawska, M. Urban Allotment Gardens in Poland: Implications for Botanical and Landscape Diversity. J. Ethnobiol. 2018, 38, 123-137. [CrossRef]

16. Chiesura, A. The role of urban parks for the sustainable city. Landsc. Urban Plan. 2004, 68, 129-138. [CrossRef]

17. Armstrong, D. A survey of community gardens in upstate New York: Implications for health promotion and community development. Health Place 2000, 6, 319-327. Available online: https:/ / pdfs.semanticscholar.org/bdfd/36f72519480f8eb717a09d6e6ea14c41d8b9.pdf?_ga=2.213836061. 888276126.1537970913-396387087.1537970913 (accessed on 4 March 2018). [CrossRef]

18. Blair, D.; Giesecke, C.; Sherman, S. A dietary, social and economic evaluation of the Philadelphia Urban Gardening Project. J. Nutr. Educ. 1991, 23, 161-167. [CrossRef]

19. Ulrich, R.S. Natural versus urban scenes, some psychophysical eVects. Environ. Behav. 1981, 13, 523-556. [CrossRef]

20. Kaplan, R. Some psychological benefits of gardening. Environ. Behav. 1973, 5, 145-161. [CrossRef]

21. Sommer, R.; Learey, F.; Summitt, J.; Tirrell, M. Social benefits of resident involvement in tree planting: Comparison with developer-planted trees. J. Arboric. 1994, 20, 323-328.

22. Paxton, A. Food Miles Action Pack-A Guide to Thinking Globally and Eating Locally; Sustaining Agriculture and Food Alliance (SAFE): London, UK, 1996.

23. DeSilvey, C. Cultivated histories in a Scottish allotment garden. Cult. Geogr. 2003, 10, 442-468. [CrossRef]

24. Garnett, T. Growing Food in Cities; National Food Alliance/Sustaining Agriculture and Food Alliance (NFA/SAFE): London, UK, 1996; Available online: http://library.uniteddiversity.coop/REconomy_ Resource_Pack/Community_Food/Growing_Food_in_Cities.pdf (accessed on 4 March 2018).

25. Irvine, S.; Johnson, L.; Peters, K. Community gardens and sustainable land use planning: A case-study of the Alex Wilson Community Garden. Local Environ. 1999, 4, 33-46. [CrossRef]

26. Wiltshire, R.; Azuma, R. Rewriting the Plot: Sustaining allotments in the UK and Japan. Local Environ. 2000, 5, 139-151. [CrossRef]

27. Domene, E.; Saurí, D. Urbanization and class-produced natures: Vegetable gardens in the Barcelona Metropolitan Region. Geoforum 2007, 38, 287-298. [CrossRef]

28. Crouch, D.; Ward, C. The Allotment: Its Landscape and Culture, 3rd ed.; Five Leaves Nottingham: Nottingham, UK, 1997; p. 320, ISBN 978-0907123910.

29. Spilková, J.; Vágner, J. The loss of land devoted to allotment gardening: The context of the contrasting pressures of urban planning, public and private interests in Prague, Czechia. Land Use Policy 2016, 52, 232-239. [CrossRef]

30. Nilsen, M. The Working Man's Green Space: Allotment Gardens in England, France, and Germany, 1870-1919; University of Virginia Press: Charlottesville, VA, USA, 2014; p. 248, ISBN 978-0813935089.

31. Stein, H. Inseln im Häusermeer: Eine Kulturgeschichte des Deutschen Kleingartenwesens bis zum Ende des Zweiten Weltkriegs; Reichsweite Tendenzen und Groß-Hamburger Entwicklung, 2nd ed.; Peter Lang GmbH, Internationaler Verlag der Wissenschaften: Frankfurt am Main, Germany, 2000; p. 258, ISBN 978-3631366325.

32. Warnecke, P. Laube Liebe Hoffnung (Kleingartengeschichte); W. Wächter: Berlin, Germany, 2001; p. 264, ISBN 978-3000075087. 
33. Kuhn, G. 'Wildes' Siedeln und 'stille' Suburbanisierung. Von den Wohnlauben zu den privaten Stadtrandsiedlungen. In Wohnen in der Großstadt: 1900-1939: Wohnsituation und Modernisierung im europäischen Vergleich; Janatková, A., Kozinska-Witt, H., Eds.; Franz Steiner Verlag: Stuttgart, Germany, 2006; pp. 111-132, ISBN 978-3515083454.

34. Lorbek, M.; Martinsen, M. Allotment Garden Dwellings: Exploring Tradition and Legal Framework. Urbani Izziv 2015, 26, 98-113. [CrossRef]

35. Pawlikowska-Piechotka, A. Tradycja Ogrodów Działkowych w Polsce; Novae Res: Gdynia, Poland, 2010; p. 104, ISBN 978-8361194118.

36. Weirich, M. Kleingärten in Europa: Überblick. Dokumentation Kongress. In Proceedings of the Kongress Kleingärten mit Zukunft—Lebenswerte Stadt, Hamburg, Germany, 11-13 May 2007; Available online: http: / / www.hamburg.de/contentblob /134998/data/dokumentation-kleingartenkongress-druckversion.pdf (accessed on 4 March 2018).

37. Bellows, A.C. One hundred years of allotment gardens in Poland. Food Foodways 2004, 12, 247-276. [CrossRef]

38. Jakowiew, A.; Kuc, O. Ustawa o Rodzinnych Ogrodach Działkowych. Komentarz; Wolters Kluwer Polska: Warszawa, Poland, 2014; p. 256, ISBN 978-8327806741.

39. Statistical Yearbooks of Agriculture. 2015. Available online: https://stat.gov.pl/obszary-tematyczne/ roczniki-statystyczne/roczniki-statystyczne/rocznik-statystyczny-rolnictwa-2015,6,9.html (accessed on 4 March 2018).

40. Statistical Yearbooks of Agriculture. 2016. Available online: https://stat.gov.pl/obszary-tematyczne/ roczniki-statystyczne/roczniki-statystyczne/rocznik-statystyczny-rolnictwa-2016,6,10.html (accessed on 4 March 2018).

41. Statistical Yearbooks of Agriculture. 2017. Available online: https://stat.gov.pl/obszary-tematyczne/ roczniki-statystyczne/roczniki-statystyczne/rocznik-statystyczny-rolnictwa-2017,6,11.html\# (accessed on 4 March 2018).

42. Crouch, D. Allotments in England-Report of Survey 2006. Available online: http:/ / allotmentresources. org/wp-content/uploads/2013/09/CROUCH_2006.pdf (accessed on 4 March 2018).

43. Djokić, V.; Ristić Trajkovića, J.; Furundžića, D.; Krstića, V.; Stojiljković, D. Urban garden as lived space: Informal gardening practices and dwelling culture in socialist and post-socialist Belgrade. Urban For. Urban Green. 2018, 30, 247-259. [CrossRef]

44. Tóth, A.; Duží, B.; Vávra, J.; Supuka, J.; Bihuňová, M.; Halajová, D.; Martinát, S.; Nováková, E. Changing Patterns of Allotment Gardening in the Czech Republic and Slovakia. Nat. Cult. 2018, 13, 162-188. [CrossRef]

45. Dylewski, R.; Nowakowski, M.; Szopa, M. Poradnik Urbanisty; Towarzystwo Urbanistów Polskich: Oddział w Warszawie, Poland, 2003; p. 226, ISBN 978-8385892441.

46. Announcement of the National Council of the Polish Allotment Federation of March 2, 2017 on Claims to Land Occupied by Allotment Gardens as of January 1, 2017. Available online: http: / pzd.pl/artykuly/19746/188/Komunikat-KR-PZD-z-dn-2-marca-2017-r-ws-roszczen-dogruntow-ROD-wg-stanu-na-dzien-1-01-2017-r.html (accessed on 4 March 2018).

47. The Decree of 25 June 1946 on Allotment Gardens. Official Journal of 1946, No. 34, Item 208. Available online: http:/ / prawo.sejm.gov.pl/isap.nsf/download.xsp/WDU19460340208/O/D19460208.pdf (accessed on 10 October 2018).

48. The Act of 24 April 1960 Civil Code Official Journal of 2018, Item 1025 (as Amended). Available online: http:/ / prawo.sejm.gov.pl/isap.nsf/download.xsp/WDU20180001025/U/D20181025Lj.pdf (accessed on 10 October 2018).

49. The Act of 14 June 1960 Code of Administrative Procedure. Official Journal of 2017, Item 1257 (as Amended). Available online: http:/ / prawo.sejm.gov.pl/isap.nsf/download.xsp/WDU20170001257/U/D20171257Lj. pdf (accessed on 4 March 2018).

50. Announcement of the Polish Allotment Federation of January 31, 2018 on the Regulation of the Legal Status of Land in Family Allotment Gardens. Available online: http:/ / pzd.pl/artykuly/21159/188/Komunikat-wsprawie-regulacji-stanu-prawnego-gruntow-ROD.html (accessed on 4 March 2018).

51. Kraków Development Strategy. I Want to Live Here. Kraków 2030 Adopted by the Resolution of the Kraków City Council No. XCIV/2449/18 of February 7, 2018. Available online: www.bip.krakow.pl/?dok.id+94892 (accessed on 4 March 2018). 
52. The Municipal Spatial Information System. Available online: http://msip2.um.krakow.pl/ (accessed on 4 March 2018).

53. Trembecka, A. Selected problems of regulating legal status of allotment gardens on example of city of Krakow. Geomat. Environ. Eng. 2018, 12, 101-110. [CrossRef]

54. Trembecka, A. Gospodarka Nieruchomościami: Teoria i Praktyka; Wydawnictwa AGH: Kraków, Poland, 2015; p. 305, ISBN 978-8374647533.

55. Trembecka, A.; Kwartnik-Pruc, A. Problems of Real Estate Management with Respect to Claims for Restitution of Expropriated Properties. Real Estate Manag. Valuat. 2018, 26, 105-112. [CrossRef]

56. Google Maps. Available online: https://www.google.pl/maps (accessed on 10 October 2018).

2018 by the authors. Licensee MDPI, Basel, Switzerland. This article is an open access article distributed under the terms and conditions of the Creative Commons Attribution (CC BY) license (http://creativecommons.org/licenses/by/4.0/). 